\title{
BEFORE THE NEOLITHIZATION: CAUSES OF MESOLITHIC DIVERSITY IN THE SOUTHERN BALKANS
}

\author{
MAŁGORZATA KACZANOWSKA-JANUSZ K. KOZŁOWSKI
}

\author{
Jagellonian University, \\ ul. Gołebia 24, 31007 Kraków, Poland \\ janusz.kozlowski@uj.edu.pl, malgorzatakacz@wp.pl
}

\begin{abstract}
The Balkans, particularly southern and central, were sparsely populated in the Mesolithic and the occupation networks in that period were discontinous and highly diversified, contrasting with the density and homogeneity of the Early Neolithic. The aim of this paper is to describe the environmental conditions of the Mesolithic sites in relation to Early Holocene climatic fluctuations and to discuss the causes of specificity and diversity of culture and behaviour at this period.

Some general trends are observable in the adaptation to Early Holocene environments (trends in faunal exploitation; for ex. shift from high ranked large game to low ranked small animals) but also particular adaptations to local conditions (technological changes due to difficulties in access to better quality lithic raw materials, adaptations to coastal or to terrestrial resources reflecting the unique features of site use, etc).

The diversity of the Mesolithic is also reflected in cultural taxonomy: in some sequences continuity of the Balkan Epigravettian techno-morphological tradition can be seen as opposed, in other sequences, to highly isolated groups with technology and tool morphology adapted to local raw materials and specific activities. The Balkan Mesolithic was not completely cut-off from the Western Mediterranean techno-morphological influences (particularly in Southern Greece) and from the Anatolian lithic traditions (seen only in the Northern Aegean). A more intensive network of marine contacts is confirmed by obsidian circulation in the Aegean Basin.
\end{abstract}

Keywords: Mesolithic, Epipalaeolithic/Final Palaeolithic, Early Holocene, taxonomy, human adaptations

\section{INTRODUCTION}

Among the several tens of Mesolithic sites recorded in the Southern Balkans (Fig. 1) only seven have been systematically excavated and radiometrically dated to the Early Holocene (Fig. 2): namely the Franchthi Cave, ${ }^{1}$ Klissoura Cave I, ${ }^{2}$ Cyclops Cave on Gioura Island, ${ }^{3}$ Maroulas on Kythnos, ${ }^{4}$ Kerame on Ikaria, ${ }^{5}$ Sidari on Korfu, ${ }^{6}$ Theopetra Cave. ${ }^{7}$ Other sites are surface collections that are difficult to define as Mesolithic because the taxonomic diversity of Mesolithic industries is considerable.

The most important concentrations of sites assigned to the Mesolithic are known from the region of Kandia in Argolide (Western Peloponnese) ${ }^{8}$ at several locations, namely: the coast of Thilia between Meganisi and Lefkas $^{9}$ and in the Kokytos river valley in Tesprotia ${ }^{10}$

In the territory of the Central-western Balkans (the Odmut Cave in Montenegro ${ }^{11}$ ) only few Mesolithic sites have been registered, while in the Central-eastern Balkans settlement from this period is virtually absent. It is
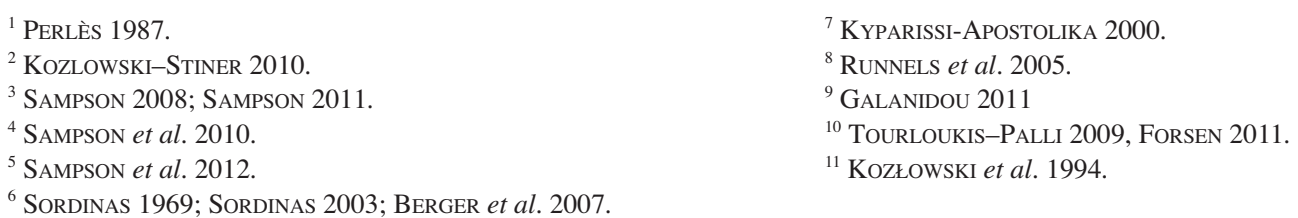


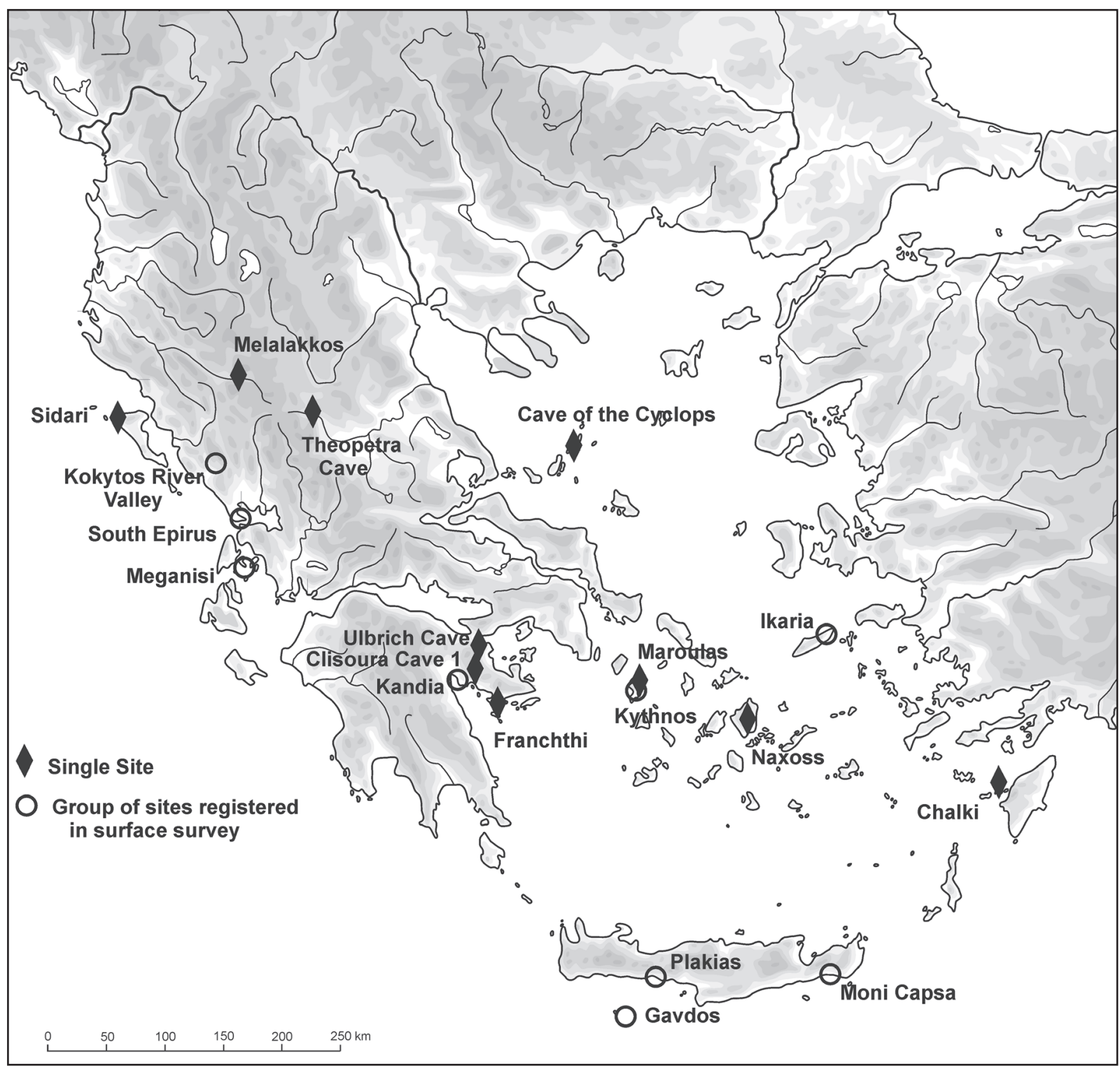

Fig. 1. Mesolithic sites in Greece

only in the Northern Balkans that major concentrations of Mesolithic sites were discovered in Croatia and Slovenia and in the region of the Iron Gate.

In this work we shall focus first of all on the sites in the Southern Balkans.

\section{SEQUENCES AND DATING OF THE MESOLITHIC}

Most cave sites are multilayer occupations where Mesolithic sequences were registered sometimes in between Neolithic and Late Palaeolithic layers (Sarakenos, Franchthi, Theopetra), or overlying Late Palaeolithic layers (Klissoura, Cave 1). It should be emphasized that a chronological hiatus - of as much as several thousand years occurs between the Late Palaeolithic and the Mesolitic (Klissoura, Cave 1, Sarakenos, Franchthi). This hiatus can be correlated with the discontinuity of techno-morphological features of lithic assemblages (e.g. in the Sarakenos Cave) or with the continuity of Epigravettian traits (e.g. in the Klissoura Cave 1). 


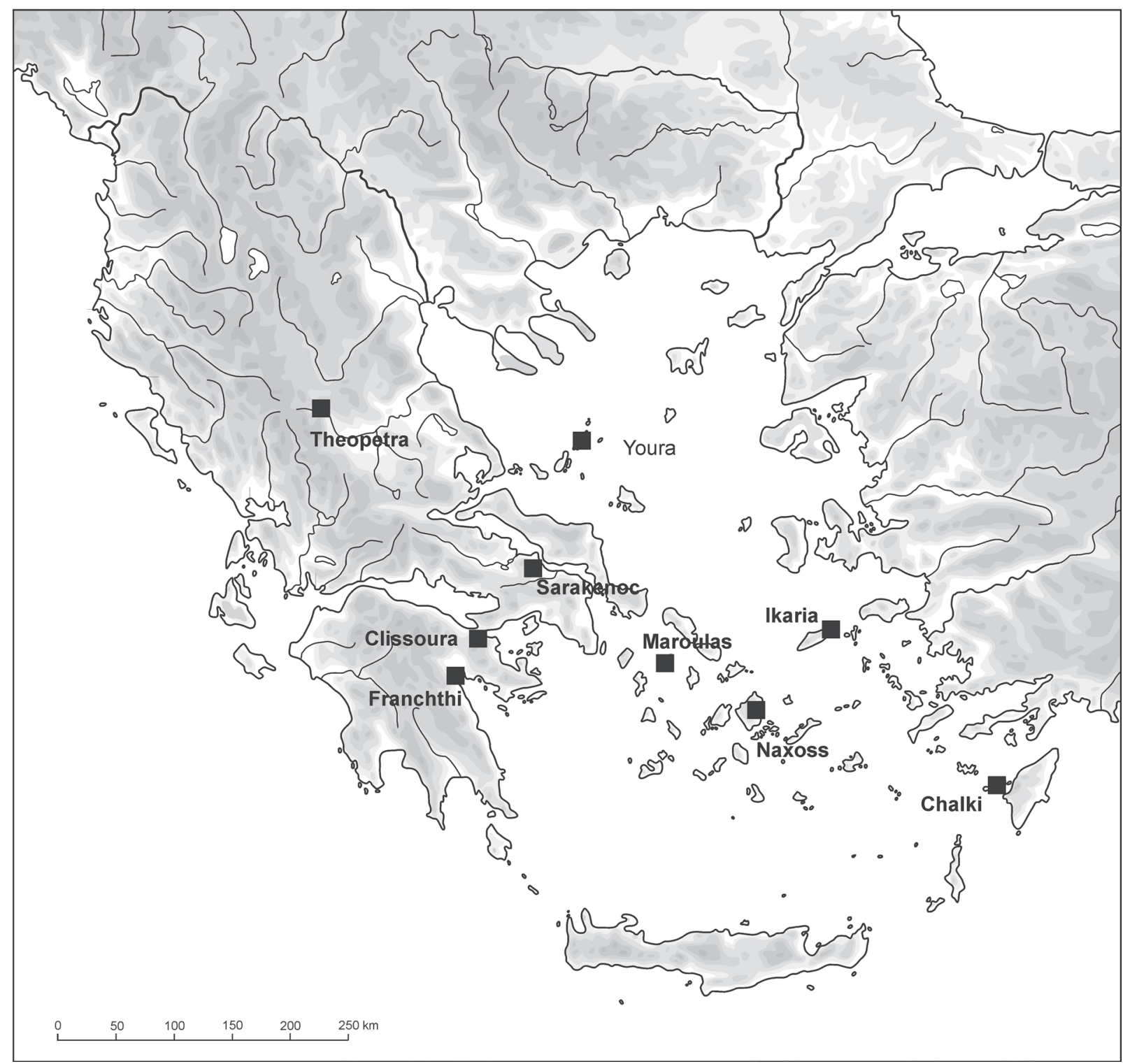

Fig. 2. Systematically explored and dated sites in Greece

Most Mesolithic sites provided a series of radiometric (mainly AMS) data (Fig. 3) in the interval between the beginning of the Holocene [on charcoals $9440 \pm 40 \mathrm{BP}=8771-8642$ cal BC - Maroulas; ${ }^{12} 9430 \pm 160$ $\mathrm{BP}=8580-8526 \mathrm{cal} \mathrm{BC}-$ Franchthi, Phase VII ${ }^{13}$ and the period after the Early Holocene Event $[8190 \pm 80$ $\mathrm{BP}=7429-6829 \mathrm{cal}$ BC - Franchthi, Phase IX; $7960 \pm 40$ BP $=7028-6778 \mathrm{cal} \mathrm{BC}-$ Sarakenos, layer $4,{ }^{14}$ Some dates for the Mesolithic are even younger $\left(7670 \pm 120 \mathrm{BP}=6549 \mathrm{cal} \mathrm{BC}-\right.$ Sidari $\left.^{15}\right]$. The dates between 8240 and $7611 \mathrm{BP}$ are contemporaneous with the dates for the Early Neolithic sites in the Eastern Balkans ${ }^{16}$ (Fig. 4).

${ }^{12}$ FACORELLIS et al. 2010.

${ }^{13}$ Perlès 2001.

${ }^{14}$ SAMPSON et al. 2008; KACZANOWSKA et al. 2016

\footnotetext{
${ }^{15}$ BERGER et al. 2007

${ }^{16}$ PerLÈs 2001.
} 


\section{MAROULAS}

FRANCHTHI

\section{TEOPRTRA}

\section{CYCLOPE CAVE}

\section{SARAKENOS}

\section{SIDARI}

EN GREECE

Fig. 3. Radiometric dates for Mesolithic sites in the Southern Balkans

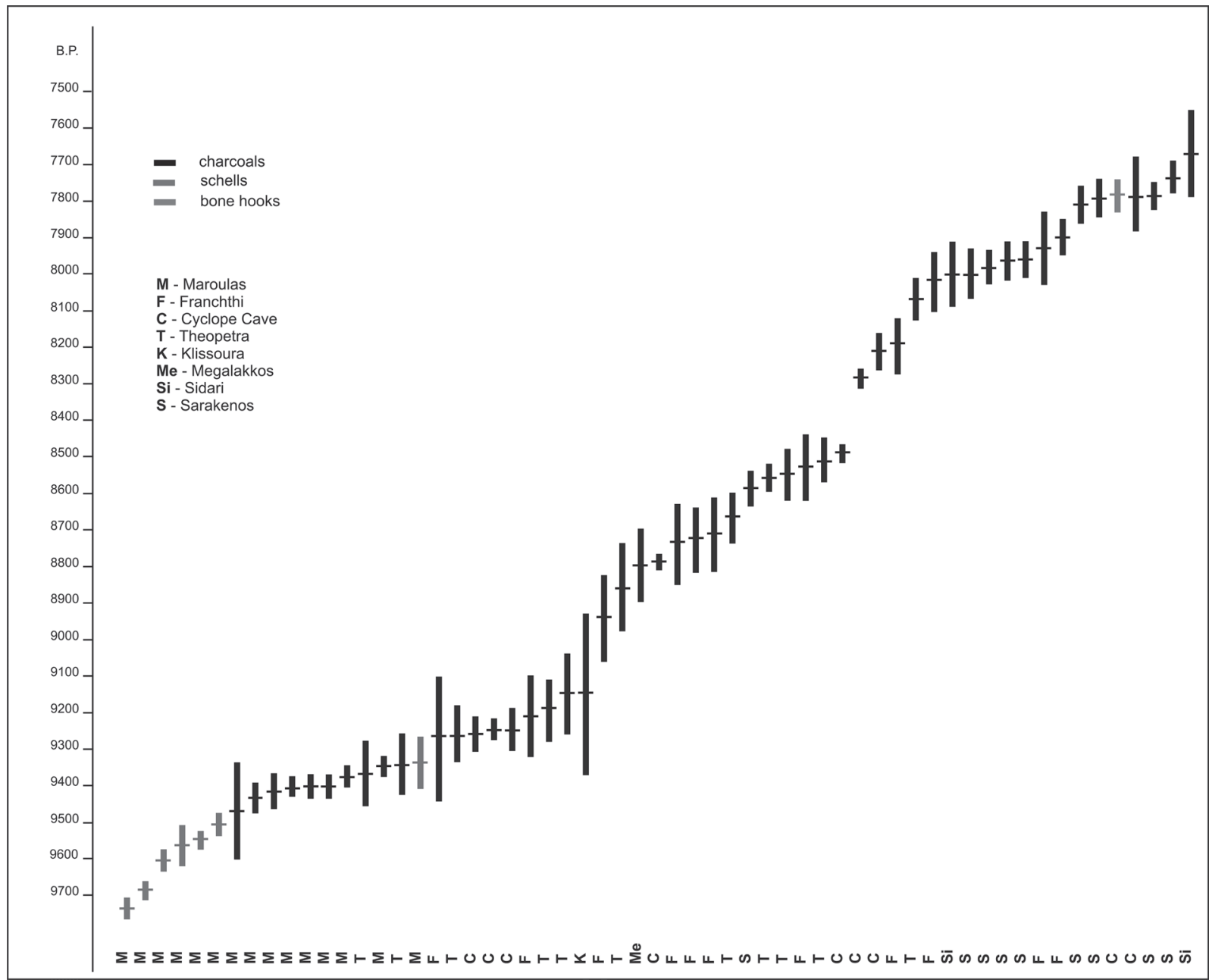

Fig. 4. Radiometric chronology of the Epipalaeolithic/Mesolithic, Initial and Early Neolithic in the Eastern Balkans 


\section{ENVIRONMENTAL CONTEXTS OF THE MESOLITHIC}

The differing environmental systems resulted in different ways of adaptations of subsistence economy to local conditions. In the effect, we can see a number of parallel adaptation systems of subsistence economy, that exploit different resources of the environment.

The systems of adaptation of Mesolithic groups to local environments are reflected in the location of sites, methods of food procurement, periods of site occupation, camp organization, system of lithic raw materials procurement, methods of blank production, tool types and tool use (tool functions).

In the Southern Balkans at least three types of environments can be seen that involved different adaptations, namely: the system associated with intracontinental sites, the littoral system and the insular system.

\section{INTRACONTINENTAL ADAPTATIONS}

The sequences representing intracontinental adaptations are known from the Klissoura Cave 1 (Fig. 5) where an Epigravettian (layer II) and a Mesolithic (layers 5a,5,3) sequence was registered. ${ }^{17}$ Unlike in the Upper Palaeolithic (Gravettian layer III' and Aurignacian layers below) this sequence shows a distinct domination of small, fast moving animals (birds, hare), followed by medium size ungulates (Ibex, fallow deer), and large ungulates (Equus hydruntinus, red deer, wild pig) come third (Fig. 6). ${ }^{18}$

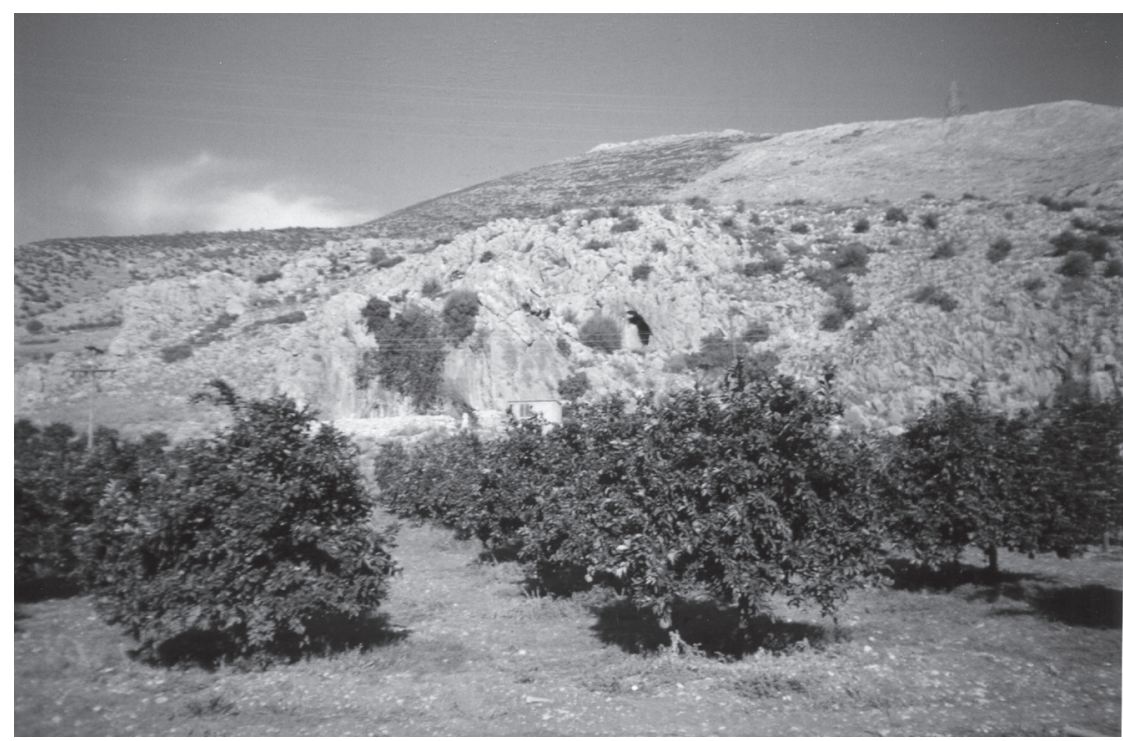

Fig. 5. Klissoura, Cave I. View of the Cave

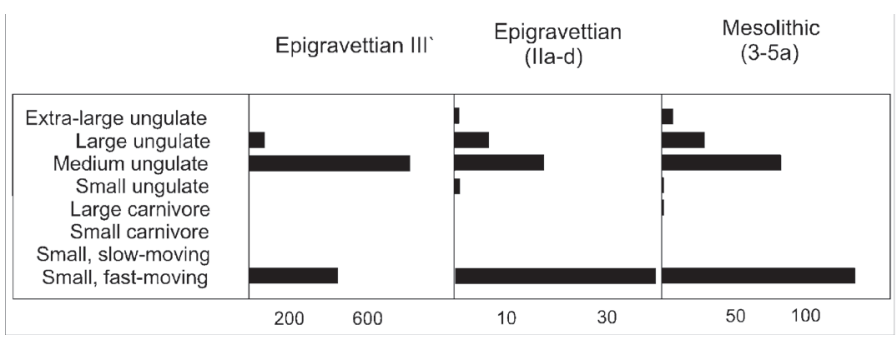

Fig. 6. Klissoura, Cave I. Faunal compositon of Epigravettian (III', IIa-d) and Mesolithic layers (3-5a) (according to B. M. Starkovich)

${ }^{17}$ KOZLOWSKI-STINER 2010.
${ }^{18}$ Starkovich 2014.

Acta Archaeologica Academiae Scientiarum Hungaricae 69, 2018 
The lithic industry from Klissoura Cave 1 layers 5a and 3 continue Epipalaeolithic (Epigravettian) traditions (Fig. 7). Index of microlithis is high; the most important group are simple backed blades and weakly arched backed pieces. Besides backed tools geometric forms also occur (rectangles and obtuse triangles) and two types of points on blades, with inverse proximal retouch and small "needle" points, present also in Sauveterrian sites in Italy (Romagnano III $^{19}$ ). However, in Cave I at Klissoura microburin technique was not applied.
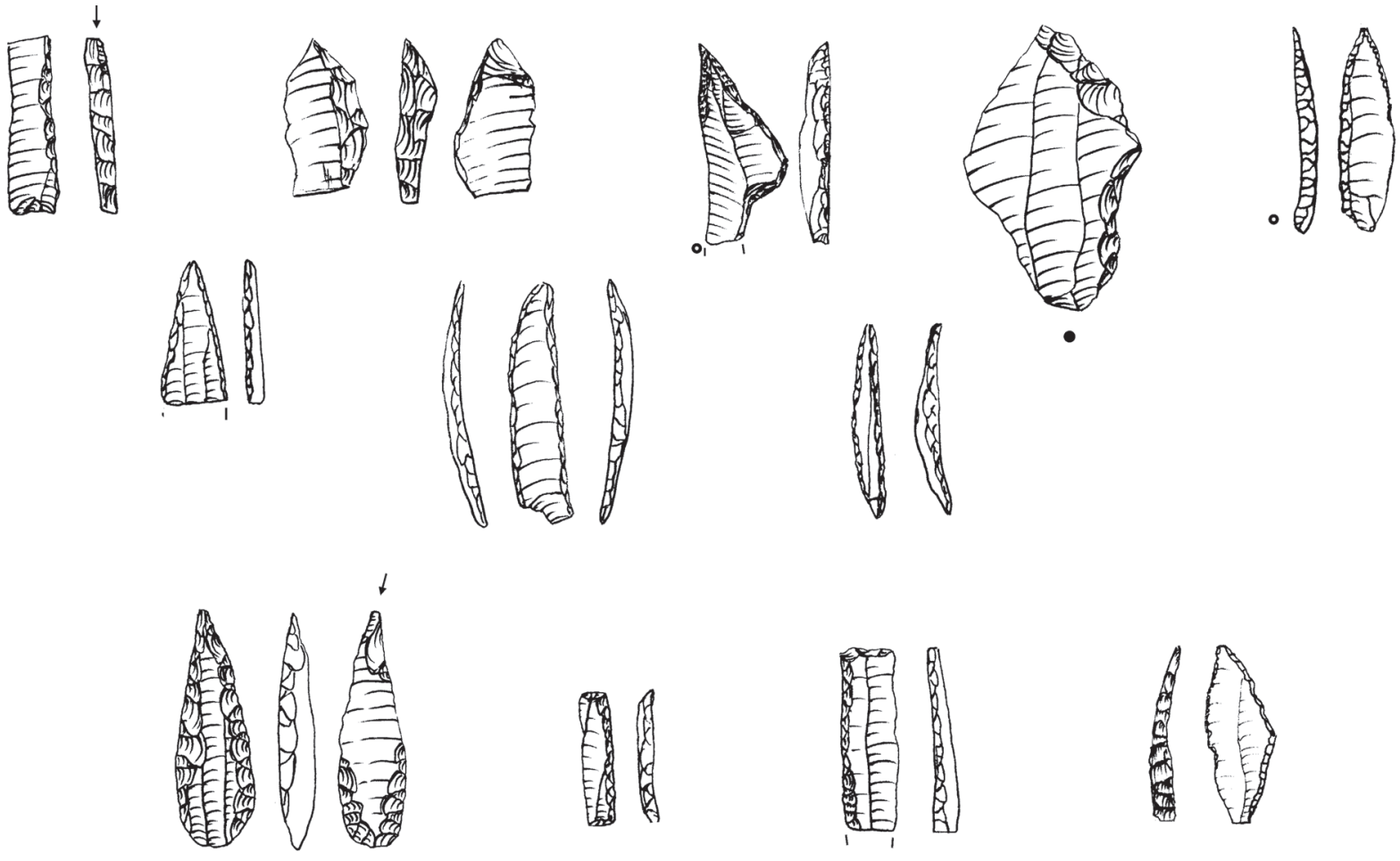

\section{0}

$3 \mathrm{~cm}$
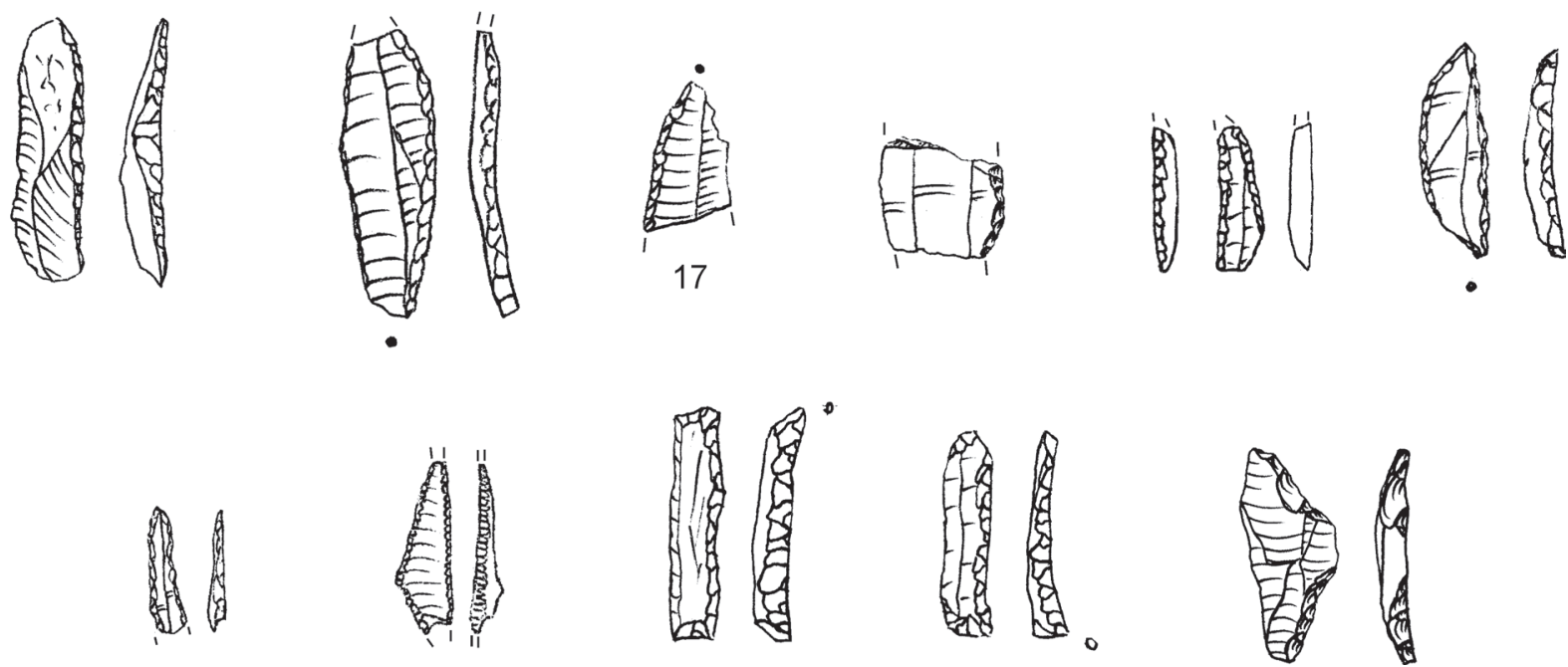

Fig. 7. Klissoura Cave I. Mesolithic artefacts from layers 5a and 3

\footnotetext{
${ }^{19}$ Broglio-KoZŁowsKi 1983.
} 
The industries from the Mesolithic sequence at Klissoura I differ from those recorded in the litoral site in the Franchthi Cave (lithic phases VII- $\mathrm{X}^{20}$ ) with their microlithic and geometrical components and in other open air sites in Argolid. ${ }^{21}$

Intracontinental adapations are also represented in a high-lying site of the Sarakenos Cave (Fig. 8, Fig. 9) above the basin of Kopaisi Lake (Beotia). ${ }^{22}$

In the Mesolithic layer 4 in the Sarakenos Cave small birds predominate (especially starling and pigeon), mostly as a result of owl eating ${ }^{23}$ in association with only single remains of large mammals. The total isolation of Mesolithic groups (notably in layer 4) is seen in the use of, nearly exclusively, local, low quality raw materials (limestone, less often sandstone and quartz). Extralocal raw materials (radiolarite and black flint) are represented by single pieces. This necessitated the use of flake techniques, denticulated-notched or chopper-type tools (Fig. 10), while blade or microflake technologies were absent. In all likelihood, the role of wooden tools was more important. Moreover, micromorphological analyses shows that large quantities of green parts of plants were brought to the cave.

\section{LITORAL ADAPTATIONS IN THE EASTERN PELOPONNESE}

They are represented by the sequence of phases VII-X in the Franchthi Cave (Fig. 11) where essential changes can be seen in the processes of adaptation between the Early and the Middle Holocene. ${ }^{24}$

Phase VII is dominated by medium-size ungulates (Cervids, Caprids) and fruits: pistaccio nuts, plum, pear and sea shells (Cyclopus neritea). A radical change takes place in phase VIII with the re-orientation of subsistence economy on marine resources. In this layer tuna remains are most numerous, while bones of fallow-deer and wild pig are few. Tuna-fishing is registered in phase IX; tuna remains occur together with some plant macroremains which include wild oat and, possibly, domesticated cereals. It is only in phase $\mathrm{X}$ that first species of - unquestionably - domesticated plants and animals appear.

The lithic industry in the Franchthi sequence indicates a hiatus between phase VI (Epipalaeolithic) with micro-backed pieces and microburin technique and phase VII where flake technique is most important. It is as late as phase VIII that trapezes and backed bladelets appear, and in phase IX flake technique re-appears and flèches tranchantes that evidence contacts with the Central Mediterranean region (Fig. 12).

\section{INSULAR ADAPTATIONS IN THE AEGEAN SEA}

These adaptations are represented by the proto-settlement at Maroulas (on the Kythnos island) ${ }^{25}$ (Fig. 13) and the site in the Cyclops Cave on the Gioura island (Northern Sporades). ${ }^{26}$ Mesolithic sites are also known form other Aegean islands, mainly from Ikaria, ${ }^{27}$ Naxos (Stelida), ${ }^{28} \operatorname{Roos}^{29}$ and Chalki (surface finds by A. Sampson).

The site of Maroulas is characterized, first of all, by the exploitation of marine resources (fishing - medium size migrating fishes such as tuna and mackerel, also near shore fish such as eel, sea bram, and scorpio fish), and land foraging (snail - mostly Helix collecting). Remains of young pigs, hare, fox and marten suggest that these animals could have been imported to the island; however pig domestication is not unlikely. The role of plant food is confirmed by sophisticated grinding equipment. The site shows an all-year-round occupation documented by bones of birds migrating in various seasons of the year. The presence of more than 30 round stone dwelling structures documents a more stable multiphase occupation of the site (Fig. 14, Fig. 15). Burials underneath the floors of dwellings and between dwellings contained contracted skeletons (Fig. 16). Moreover in some dwellings human bones were discovered.

The chipped stone industry from Maroulas and other sites on the Aegean islands was based on local raw materials (mainly quartz) used in the production of flake tools (Fig. 17). In all Mesolithic sites on the Aegean Islands

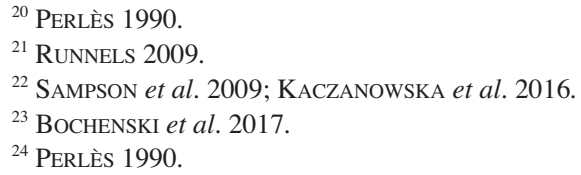

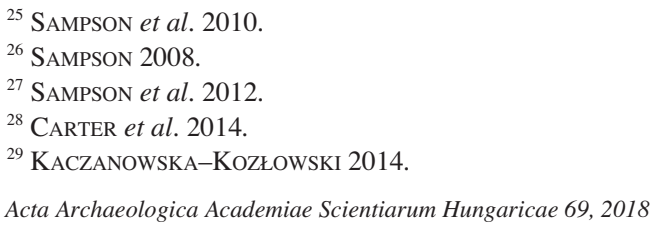




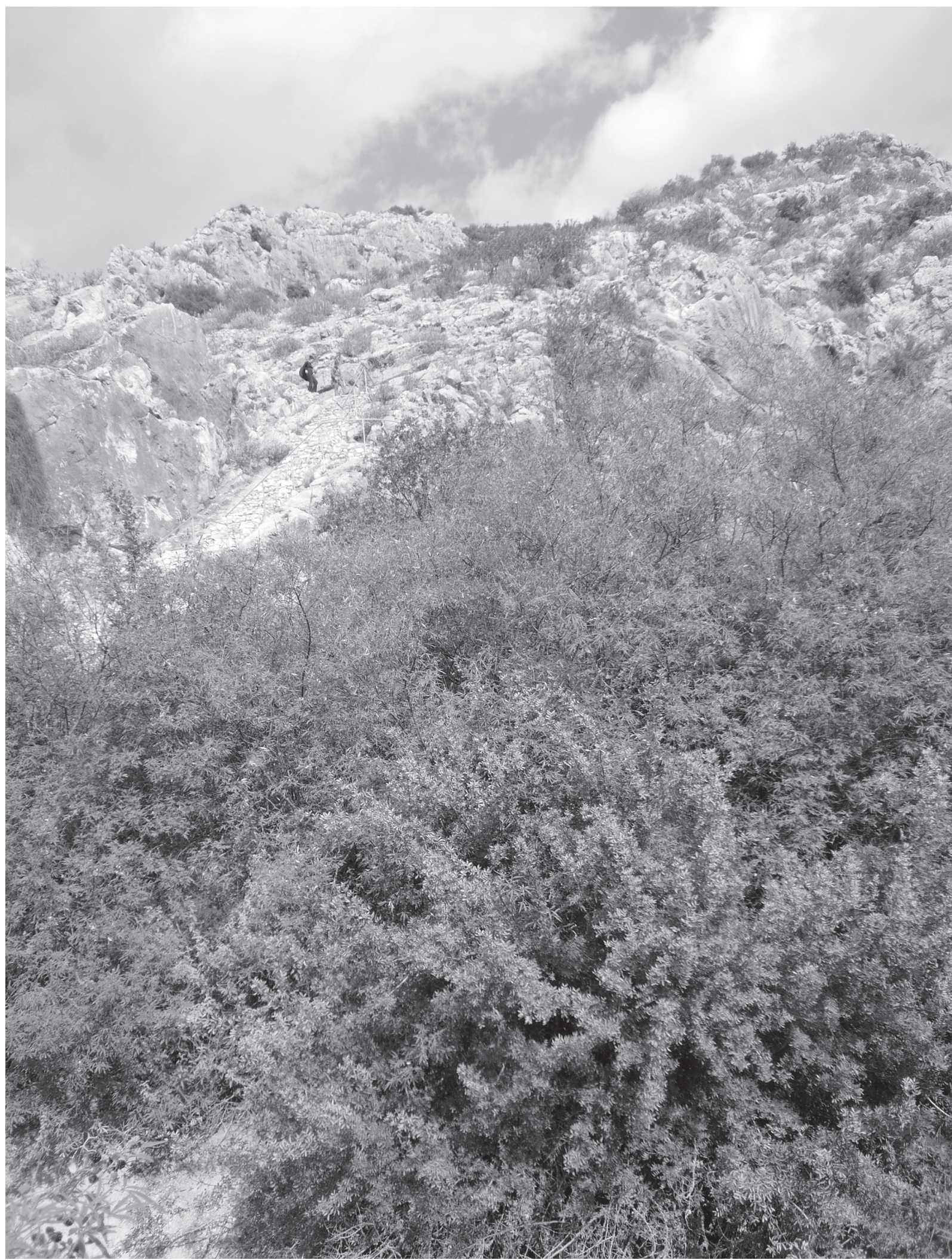

Fig. 8. Sarakenos Cave. View of the Cave 


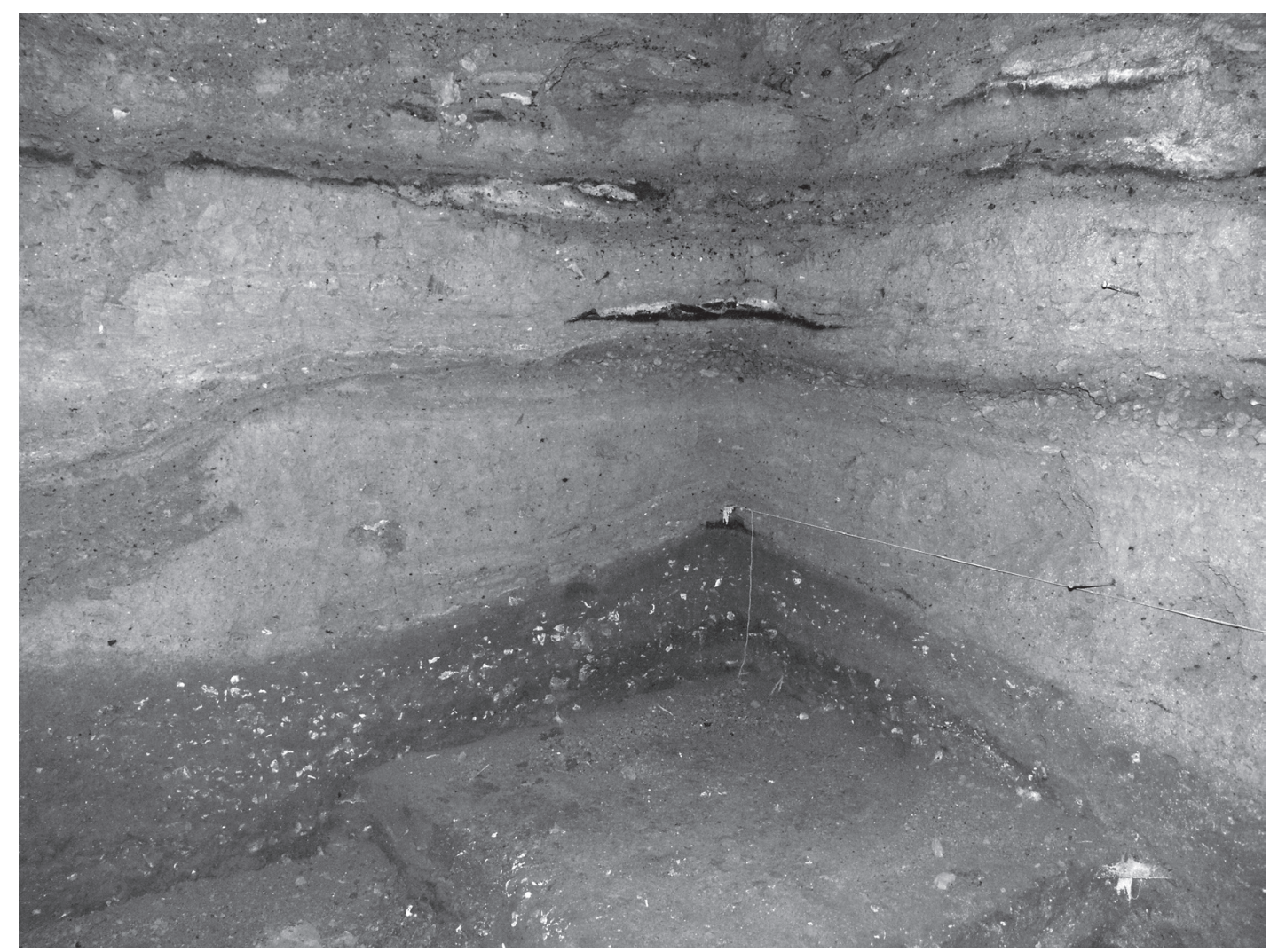

Fig. 9. Sarakenos Cave. Stratigraphic sequence: Mesolithic (layer 4), Initial Neolithic (layer 3) and Early Neolithic (layer 2)
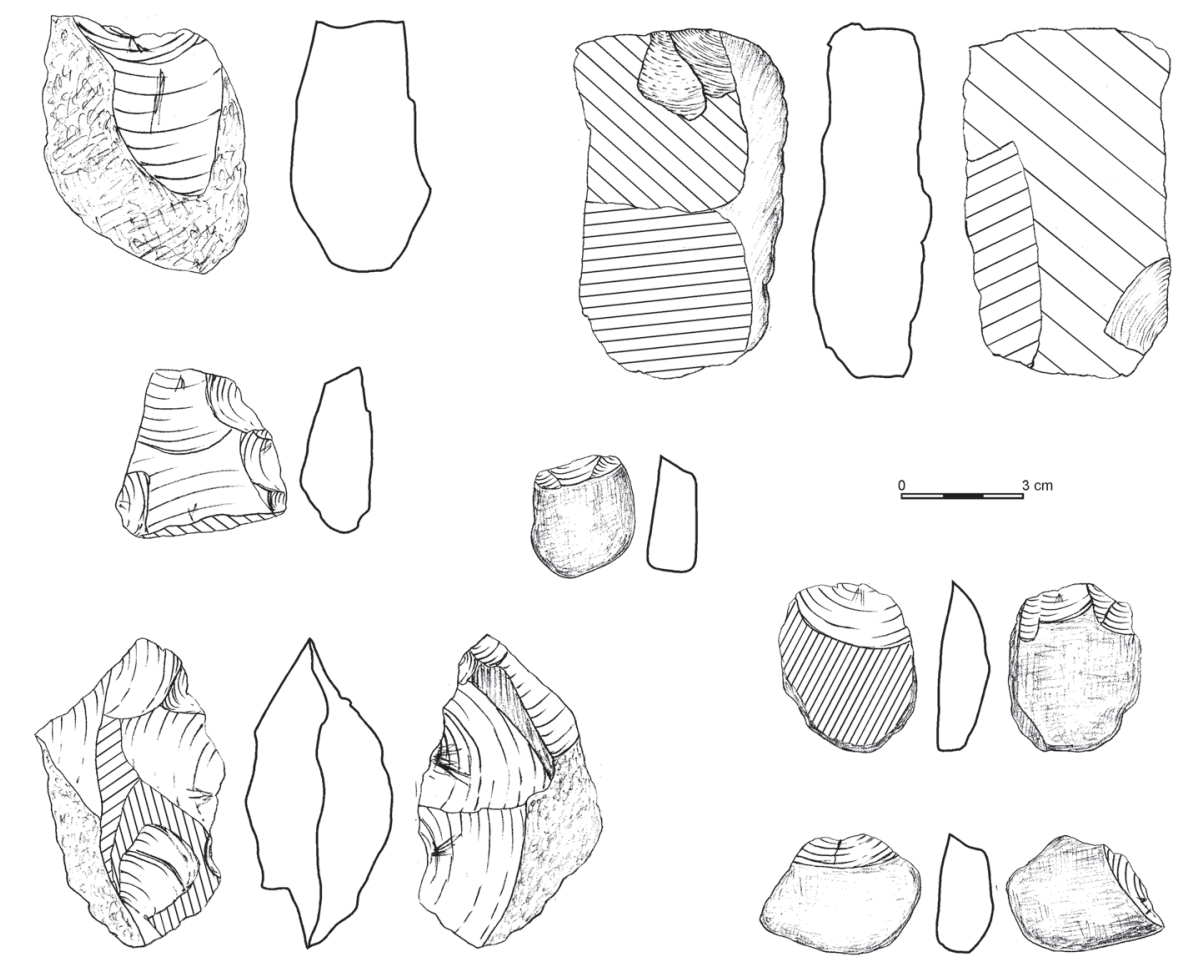

Fig. 10. Sarakenos Cave. Cores and macrotools from layer 4 


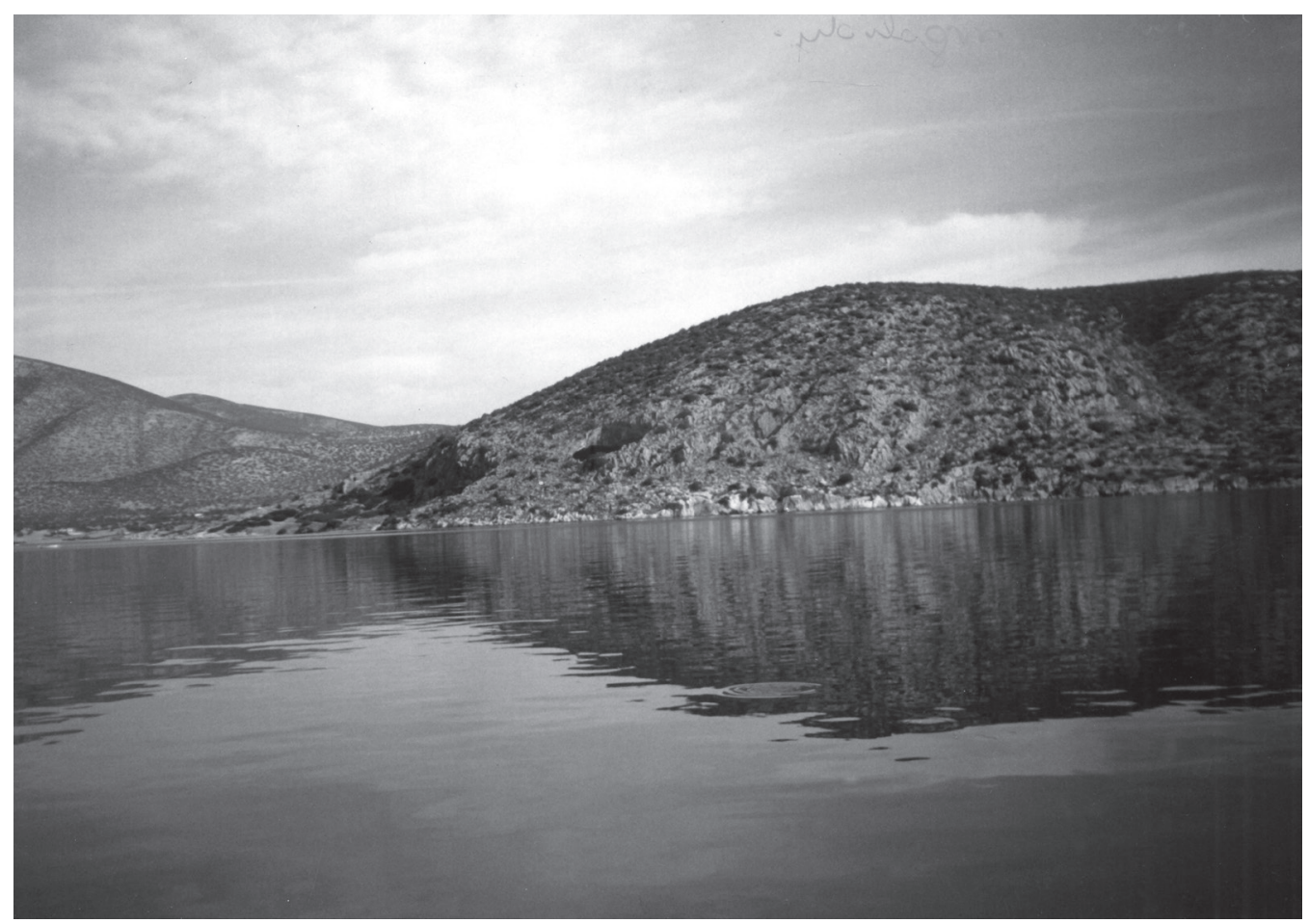

Fig. 11. Franchthi Cave. View of the Cave

\section{Phase VII}
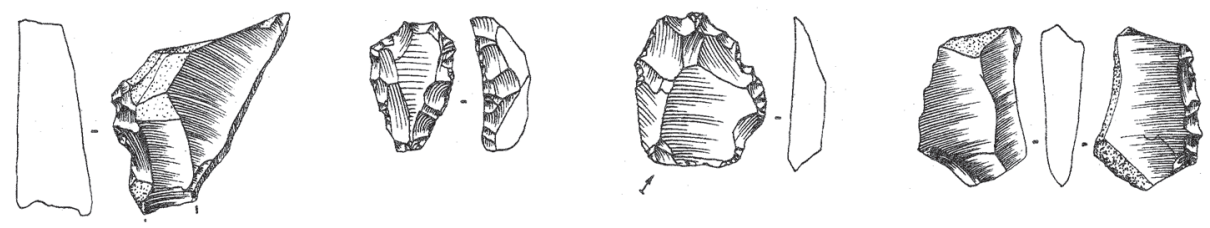

Phase VIII

b

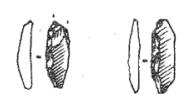

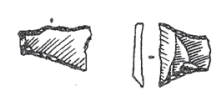

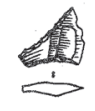<smiles>O=C(C=CC1CCCCC1)C1CCCCC1</smiles>

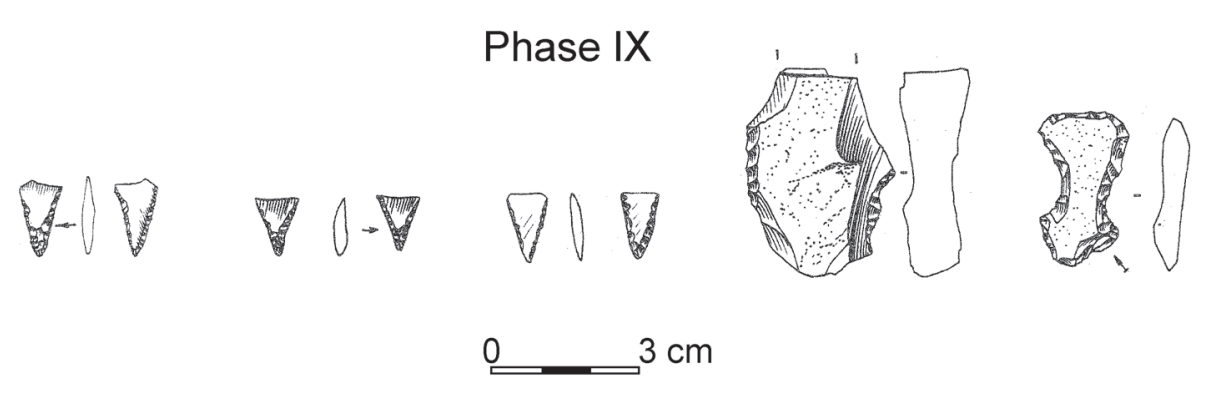

Fig. 12. Franchthi Cave. Implements from Lithic Phases VII-IX (according to C. Perlès) Acta Archaeologica Academiae Scientiarum Hungaricae 69, 2018 


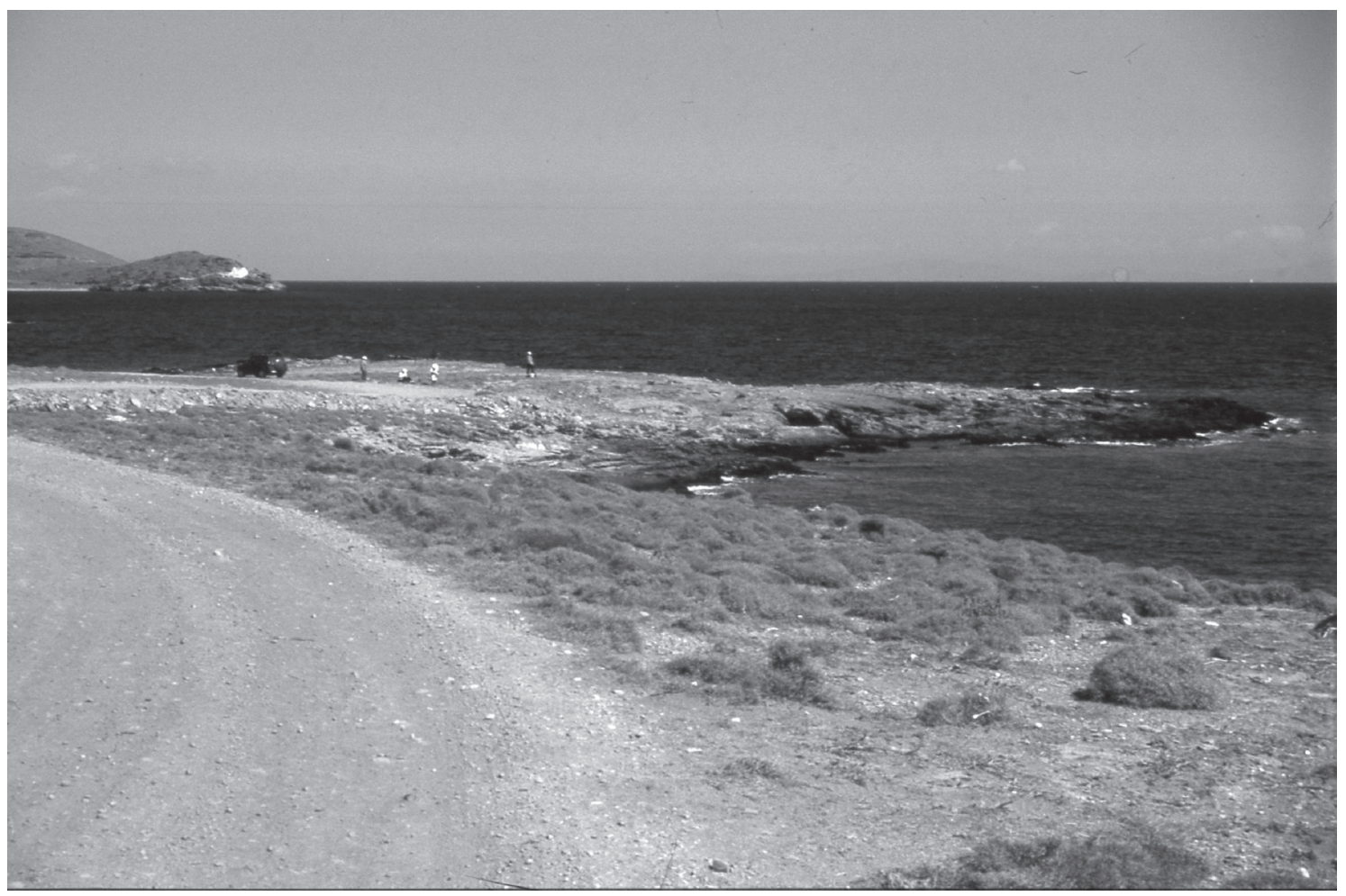

Fig. 13. Maroulas on Kythnos island. View of the site

the presence of obsidian from Melos and from Ghiali documented the systematic marine contacts across the Aegean Sea. Obsidian was used for manufacture of various types of tools (backed pieces, geometric inserts, perforatora, truncations - Fig. 17).

Fishing played a major role also on other islands, for example on the Northern Sporades. In the Cyclops Cave on the island of Gioura bone hooks (Fig. 18) and numerous fish bones (Sparidae family) were found. ${ }^{30}$ Moreover bones of goat in the early phase of domestication were also found. ${ }^{31}$

\section{MODELS OF ADAPTATION TO ENVIRONMENTAL CONDITIONS IN THE EARLY/MIDDLE HOLOCENE OF THE SOUTHERN BALKANS}

Pre-Neolithic culture units in the Aegean Sea Basin represent three models that have been distinguished on the basis of environmental conditions, economy, and the occurrence of a diversity of traditions and cultural influences (Fig. 19).

1. An intracontinental model that functioned in the territories from the Peloponnese as far as Beotia, characterized by the continuity of local Epipalaeolithic (Epigravettian) traditions on which are superimposed Sauvetarrian impacts of the Early Mesolithic of the Central Mediterranean zone. However, some groups of hunters-gatherers exhibit features of isolation such as the exploitation of low-quality lithic materials. The economy of these groups consisted in the hunting of small and medium size mammals. Some groups, notably in the territory of Beotia, persisted until the arrival of the first Neolithic settlers and, in time, adopted from them elements of food-producing economy (first of all stock-breeding).

2. A littoral model known from the coast of the Peloponnese. At the boundary between the Epipalaeolithic and the Mesolithic cultural discontinuity has been registered, and Epipalaeolithic bladelet industries were replaced

${ }^{30}$ Mylona 2003.

31 Trantalidou 2003; Trantalidou 2008. 


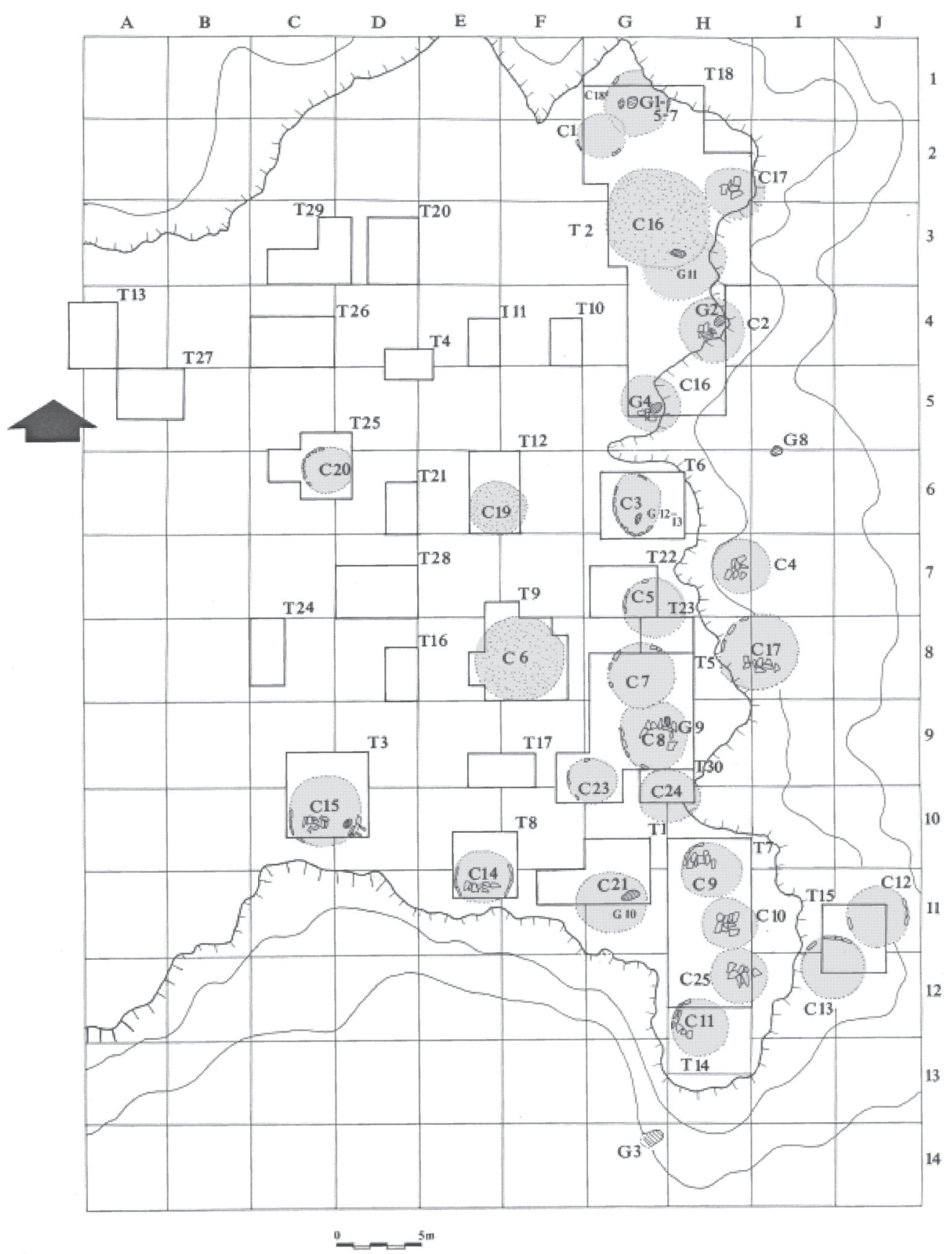

Fig. 14. Maroulas on Kythnos island. Map of the site with stone dwellings 


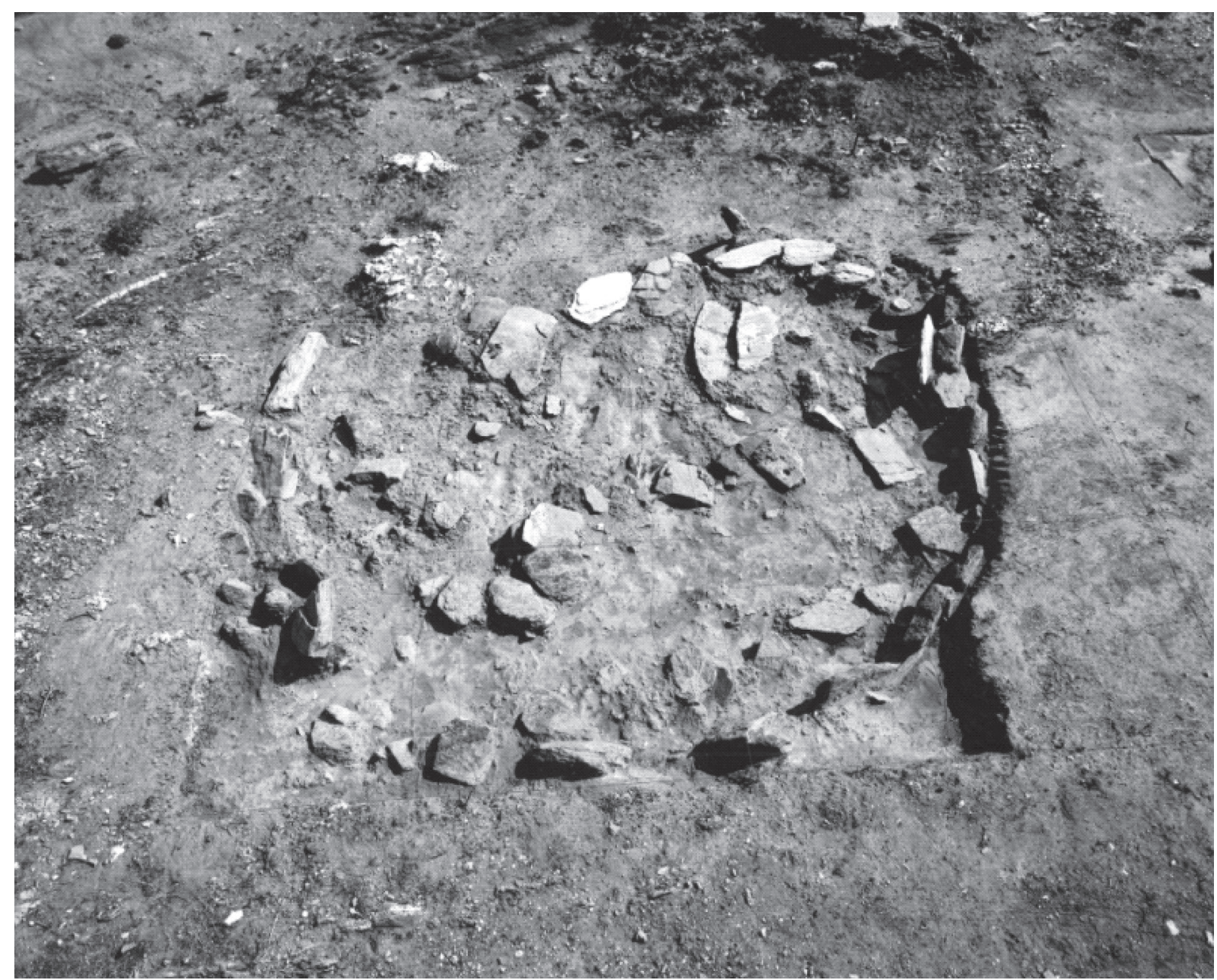

Fig. 15. Maroulas on Kythnos island. Round stone structure with pavement (Feature C3)

by Early Mesolithic flake industries. In subsistence economy the role of hunting became smaller, while fishing, especially tuna fishing in the Late Mesolithic gained in importance. The groups inhabiting littoral zones adopted, moreover, some components of the Neolithic package which encouraged some authors ${ }^{32}$ to assign these groups the "initial Neolithic". Besides contact with groups that mastered food-producing economy, in lithics, appeared elements that indicate contacts with the Western Mediterranean Late Mesolithic (e.g . flèches tranchantes).

3. The insular model is represented on the islands of the Aegean Sea that in the Mesolithic were fairly intensively settled. The setting of the Aegean islands (Kythnos, Ikaria, Naxos, Chalki, Youra) was stimulated by the development of seafaring from continental Greece. The long-distance contacts across the sea are documented by the distribution of obsidian from the islands of Melos and Ghiali. These contacts could have reached the eastern part of the Mediterranean Sea basin contributed to the transmission of elements of the Pre-ceramic Neolithic (stone architecture, burials underneath house floors, grinding stone equipment) as early as the first half of the IX ${ }^{\text {th }}$ millennium $\mathrm{BC}$. The presence of pig and goat could evidence the incipients of food producing economy in addition to fishing and land snails collecting. In all likelihood interaction must have taken place between the littoral and the insular model.

${ }^{32}$ PERLÈs 2001 


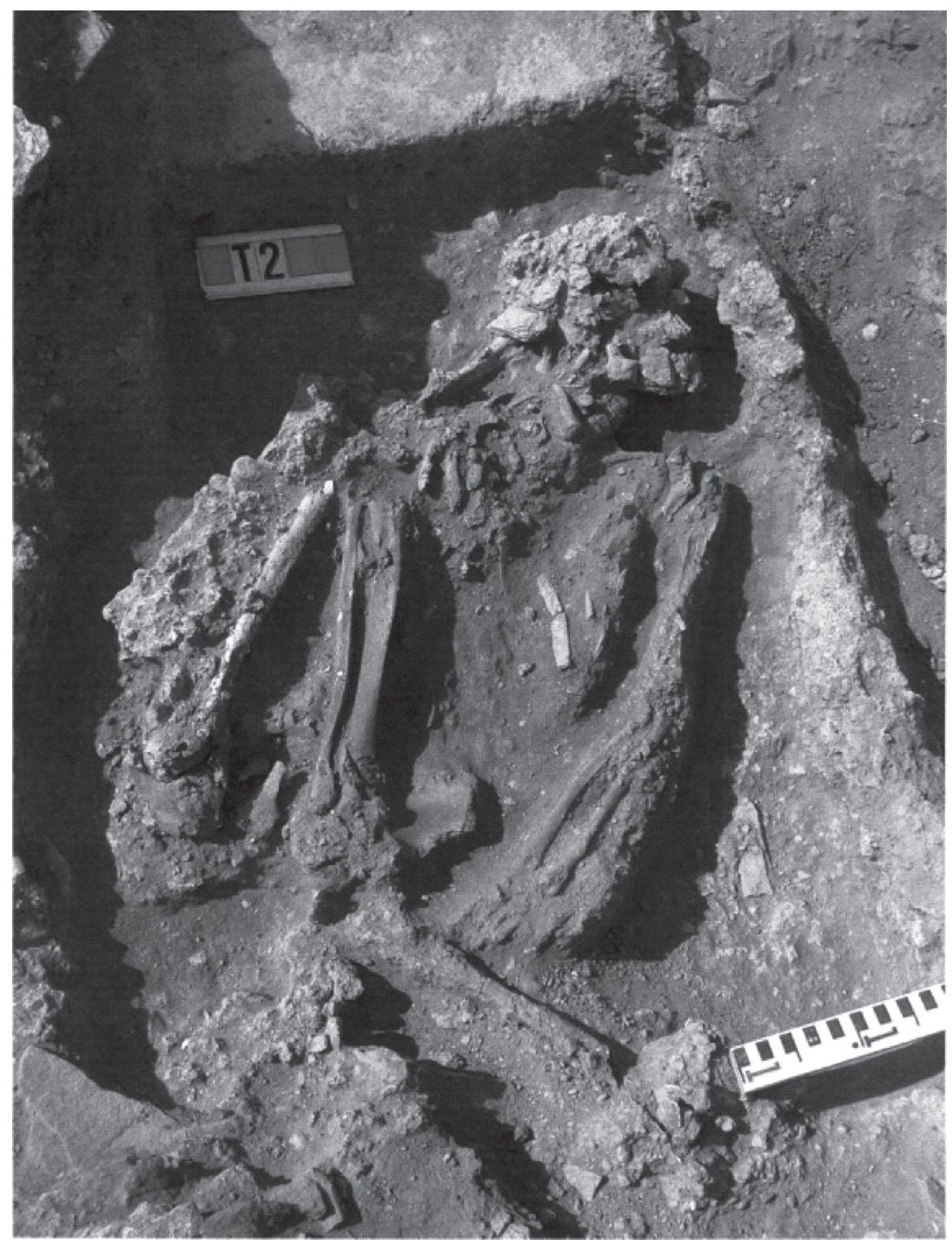

Fig. 16. Maroulas on Kythnos island. Burial 24 in dwelling structure C22 


\section{Quartz}
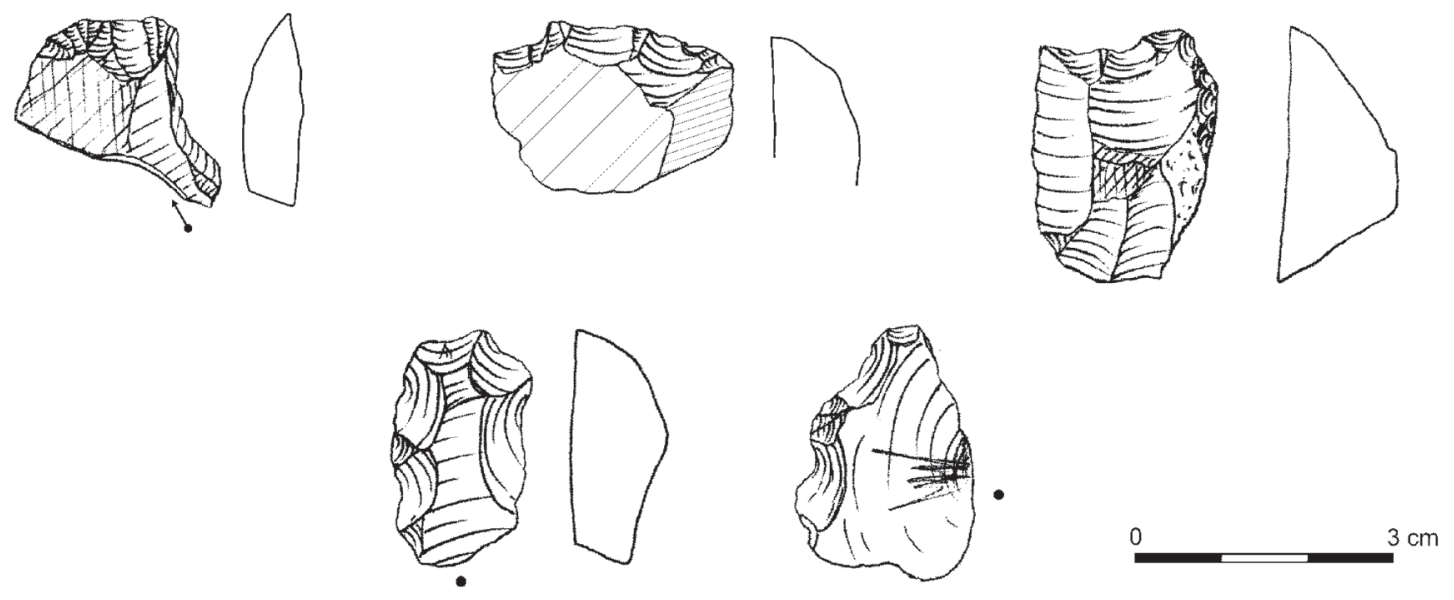

\section{Obsidian}
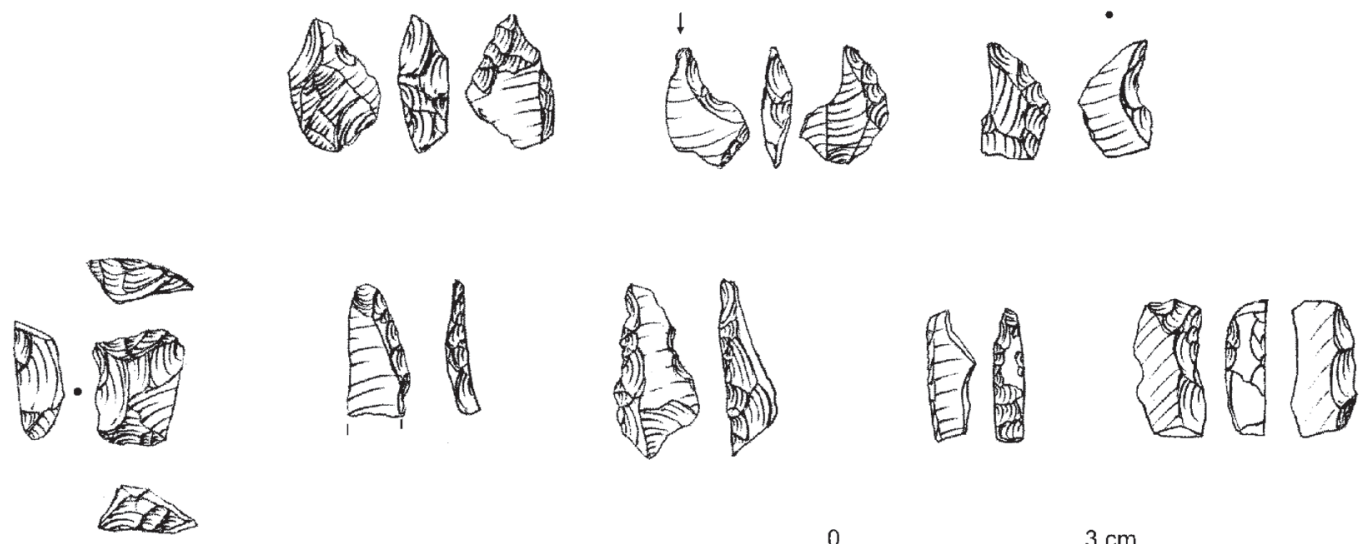

Fig. 17. Maroulas on Kythnos island. Implements from quartz and obsidian 


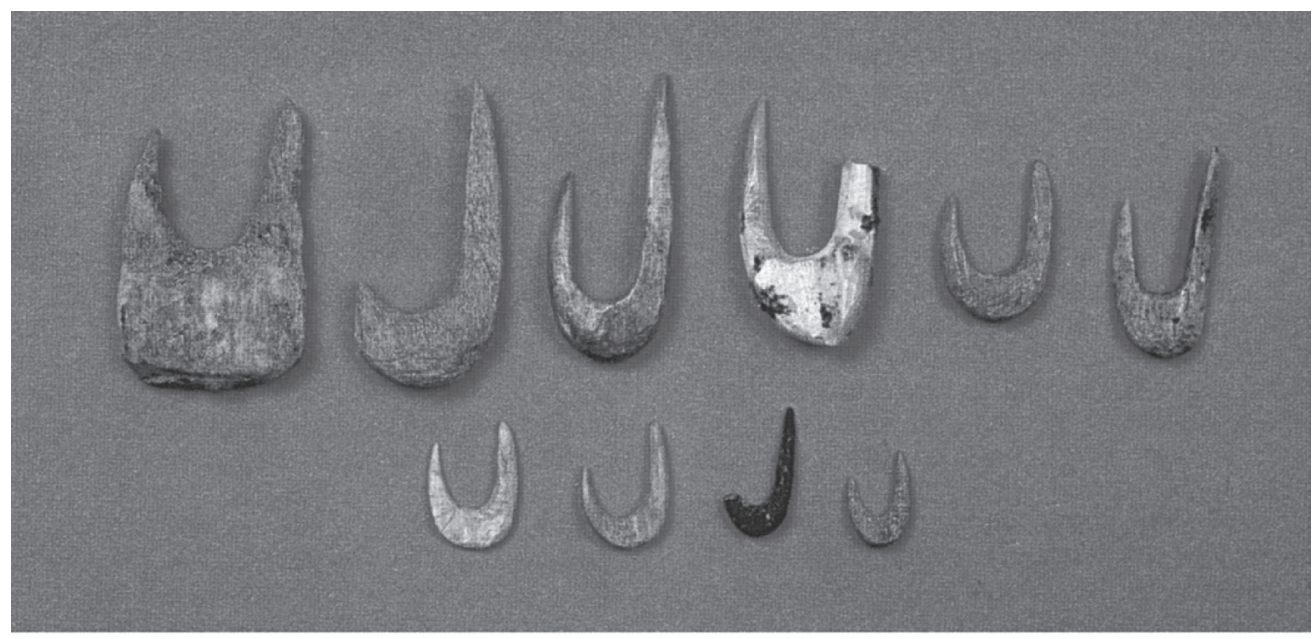

0

$5 \mathrm{~cm}$

Fig. 18. Cyclops Cave on Gioura island. Bone hooks (according to A. Sampson)

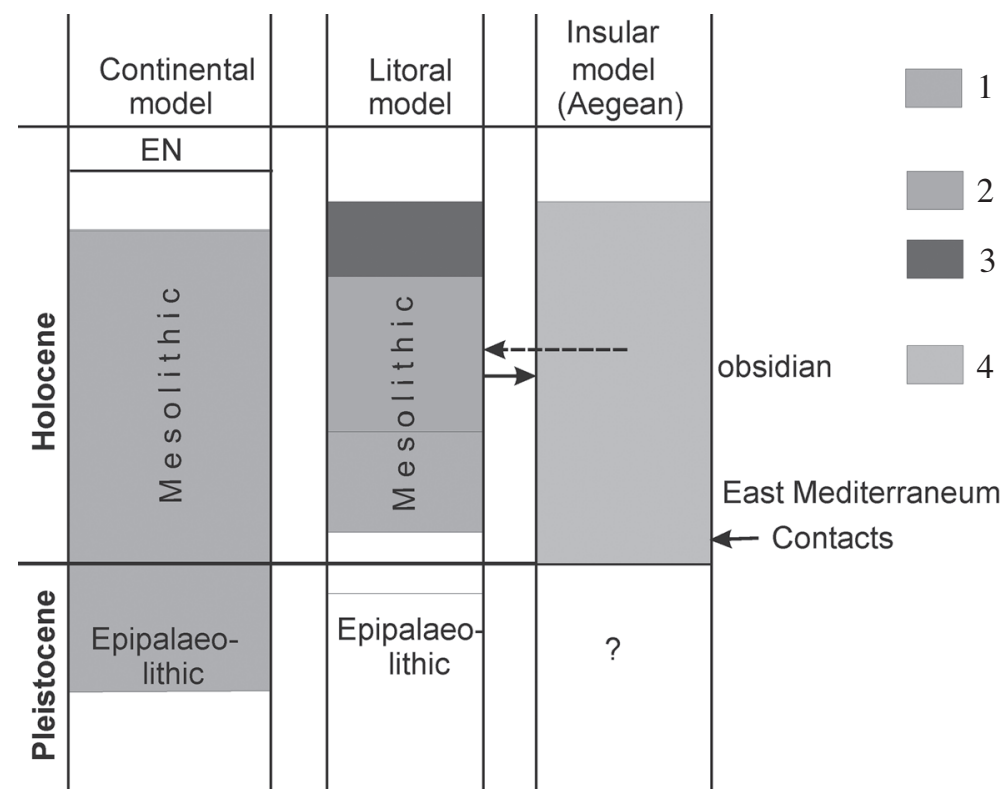

Fig. 19. Subsistence economy in intracontinetal, litoral and insular models. 1: hunting on small/medium size mammals; 2: fishing; 3 : elements of the Neolithic package; 4 : fishing, snail gathering and incipient food producing 


\section{ACKNOWLEDGMENTS}

Thanks are due to the NCN (Polish National Research Center) - Grant No 2015/19/B/HS3/00477.

\section{REFERENCES}

BERGER et al. 2007

BOCHENSKI et al. 2017

BROGLIO-KOZŁOWSKI 1983

CARTER et al. 2014

FACORELLIS et al. 2010

FORSEN 2011

GALANIDOU 2011

KACZANOWSKA et al. 2016

KACZANOWSKA-KOZŁOWSKI 2014

KozŁowsKi et al. 1994

KOZŁOWSKI- STINER 2010

KYPARISSI-APOSTOLIKA 2000

MYLONA 2003

PERLÈS 2001

PerLÈs 2001

RUNNELS 2009

RUNNELS et al. 2005

SAMPSON 2008

SAMPSON 2011

SAMPSON et al. 2008

SAMPSON et al. 2010
= J. F. Berger-G. Metallinou-J. GuilainE: Reconsidering the Mesolithic-Neolithic transition at the site of Sidari (Corfu, Greece). In: La Diffusion par Chypre, l'Egée et l'Adriatique. Ed.: C. Manen, T. Perrin et al. Toulouse 2007, 209-228.

= Z. M. BochensKi-T. TOMEK-K. WARTZ-M. KACZANOWSKA-J. K. KozŁowsKI-A. SAMPSOn: Who ate the bridrs: the taphonomy of Sarakenos Cave, Grece. Archaeological and Anthropological Science 10/41 (2017) 1-13.

= A. Broglio-S. K. KozŁowski: Tipologia ed evoluzione delle industrie mesolitiche di Romagnano III. PreAlp 19 (1983) 93-148.

$=$ T. Carter-D. Contreras-S. Doyle-D. D. Michajlović-T. Moutsiou-N. Scarpelis: The Stélida Naxos archaeological project: new data on the Middle Palaeolithic and Mesolithic Cyclades. Antiquity 88 (2014) 341.

= Y. FACORELlis-B. M. Damiata-E. VARDALA-TheOdoru-N. NTINOU-J. Southon: AMS radiocarbon dating of the Mesolithic site Maroulas on Kythnos and calculation of the regional marine reservoir effect. In: The Prehistory of the Island of Kythnos (Cyclades, Greece) and the Mesolithic Settlement at Maroulas. Eds: A. Sampson, M. Kaczanowska, J. K. Kozłowski. Krakow 2010, 127-136.

= B. Forsen: Catalogue of sites in the Central Kokytos Valley. In: The Sprotia Expedition. II.: Environment and Settlement Patterns. Eds: B. Forsen, E.Tikkala. Papers and monographs of the Finnish Institute at Athens 16. Helsiki 2011, 73-122.

$=\mathrm{N}$. GaLANIDOU: Mesolithic cave use in Greece and the mosaic of human communities. Journal of Mediterranean Archaeology 24/2 (2011) 219-242.

= M. Kaczanowska-J. K. KozŁowski-A. Sampson: The Sarakenos Cave at Akrephnion, Boeotia, Grece. II.: The Early Neolithic, the Mesolithic and the Final Palaeolithic. Kraków 2016.

= M. KacZanowsKa-J. K. KozŁowski: The Aegean Mesolithic: material culture, chronology, and networks of contacts. Eurasian Prehistory 11/1-2 (2014) 31-62.

$=$ J. K. KozlowsKI-S.K. KozŁowsKI-I. Radovanovi: Meso- and Neolithic Sequence from the Odmut Cave (Montenegro). Warszawa 1994.

= J. K. KozŁowsKI-M. C. Stiner (eds): Klissoura Cave, Argolid, Greece: the Upper Palaeolithic sequence. Eurasian Prehistory 7/2. 2010.

= N. KYPARISSI-APOSTOLIKA: Theopetra Cave: twelve years of excavations and research 1987-1998. Institute for Aegean Prehistory. Athens 2000.

$=$ D. MYLona: The exploitation of fish resources in Mesolithic Sporades. Fish remains from the Cave of Cyclope, Youra. In: The Greek Mesolithic, Problems and Perspectives. Eds: N. Galanidou, C. Perlès. BSA Studies 10. Athens 2003, 181-188.

= C. PERLÈs: Les industries lithiques taillées de Franchthi (Argolide, Grèce). II.: Les industries du Mésolithique et du Néolithique initial. Bloomington, Ind. 1990.

$=$ C. PERLÈs: The Early Neolithic in Greece. The first farming communities in Europe. Cambridge 2001.

$=$ C. RunNels: Mesolithic sites and surveys in Greece: a caves study from the southern Argolid. Journal of Mediterranean Archaeology 22/1 (2009) 57-73.

= C. Runnels-E. Panagopoulou-P. Murray-G. Tsartsidou-S. Allen-K. Mullen-E. Tourloukis: A Mesolithic landscape in Greece: testing a Site-location Model in the Argolid at Kandia. Journal of Mediterranean Archaeology 18/2 (2005) 259-285.

$=$ A. SAMPSON (ed.): The Cave of the Cyclops - Mesolithic and Neolithic networks in the Northern Aegean, Greece. Philadelphia, INSTAP 2008.

$=$ A. SAmpson (ed.): The Cyclops Cave on the Island of Youra, Greece. Mesolithic and Neolithic Networks in the Northern Aegean Basin. II.: Dietary Resources and Palaeoenviroment. Philadelphia, INSTAP 2011.

= D. Sampson-J. K. KozŁowski-M. Kaczanowska-A. Budek-A. Nadachowski-T. TomeK-B. Mį̨KINIA: Sarakenos Cave in Beotia, from Palaeolithic to the Early Bronze Age. Eurasian Prehistory 6/1-2 (2008) 199-231.

= A. SAmpson-M. KacZanowsKa-J. K. KozŁowsKi: The Prehistory of the Island of Kythnos (Cyclades, Greece) and the Mesolithic Settlement at Maroulas. Krakow 2010. 
SAMPSON et al. 2012

SORDINAS 1969

SORDINAS 2003

STARKOVICH 2014

TOURLOUKIS-PALLI 2009

Trantalidou 2003

TRANTALIDOU 2008
= A. SAMPSON-M. KaCZANOWSKA-J. K. KoZŁOWSKI: Mesolithic Occupations and Environments on the Island of Ikaria, Aegean, Greece. Folia Quaternaria 80. Kraków 2012.

= A. SORDINAS: Investigations of the prehistory of Corfu during 1964-1966. BSt 10/2 (1969) 393-424.

= A. SORDINAS: "The 'Sidarian' maritime Mesolithic non-geometric microliths in western Greece". In: The Greek Mesolithic. Eds: N. Galanidou, C. Perlès. BSA Studies 10. Athens 2003, 89-97.

= B. M. Starkovich: Optimal foraging, dietary change and site use during the Palaeolithic and Klissoura Cave 1 (southern Greece). Journal of Archaeological Science 52 (2014) 39-55.

= E. Tourloukis-O. PAlli: The first Mesolithic site of Thesprotia. In: Thesprotia Expedition. I.: Towards a Regional History. Ed. B. Forsen. Papers and monographs of the Finnish Institute at Athens 15. Helsinki 2009, 25-38.

= K. Trantalidou: Faunal remains from the earliest strata of Cave of Cyclope. In: The Greek Mesolithic Problems and Perspectives. Eds: N. Galanidou, C. Perlès. BSA Studies 10. Athens 2003, 143-172.

$=\mathrm{K}$. Trantalidou: Glipmses of Aegean Island communities during the Mesolithic and Neolithic periods: the zooarchaeological point of view. In: Horizon - Colloquium on the Prehistory of Cyclades. Eds: N. Brodie, J. Doole, G. Gavalas, C. Renfrew. Cambridge 2008, 19-27. 